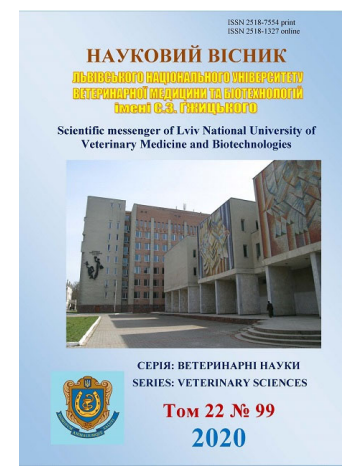

Науковий вісник Дьвівського націонадьного університету ветеринарної медицини та біотехнодогій імені С.3. Гжицького. Серія: Ветеринарні науки

\author{
Scientific Messenger of Lviv National University \\ of Veterinary Medicine and Biotechnologies. \\ Series: Veterinary sciences
}

UDC 631.8:638.19

\title{
Application of biochemical typing in veterinary medicine in bee enterobacterioses to determine Klebsiella Pneumoniae
}

\author{
O. Ye. Galatiuk, T. A. Romanishina, A. R. Lakhman, V. L. Behas, A. M. Andriichuk, L. O. Solodka \\ Polissia National University, Zhytomyr, Ukraine
}

Article info

Received 09.09.2020

Received in revised form 09.10 .2020

Accepted 12.10.2020

Polissia National University, Stary Boulevard, 7, Zhytomyr, 10008, Ukraine.

Tel.: +38-097-356-27-07

E-mail: tveterinar@gmail.com
Galatiuk, O. Ye., Romanishina, T. A., Lakhman, A. R., Behas, V. L., Andriichuk, A. M., \& Solodka, L. $O$. (2020). Application of biochemical typing in veterinary medicine in bee enterobacterioses to determine Klebsiella Pneumoniae. Scientific Messenger of Lviv National University of Veterinary Medicine and Biotechnologies. Series: Veterinary sciences, 22(99), 101-106. doi: $10.32718 /$ nvlvet 9916

The article presents laboratory diagnostics (in vitro), namely, identification of pure culture of pathogenic bacteria of Klebsiella Pneumoniae species in case of enterobacteriosis in bees in winter-spring and summer-autumn times. The purpose of the study was the biochemical typification of bacteria of the species Klebsiella Pneumoniae with humane medicine methods, that isolated in the case of dysbacteriosis of bees which have a characteristic symptomatic complex of a decrease in the strength of bee families, which leads to a decrease in the resistance of the bee family, their diarrhea, crawling, and then swarming or death of bees. Contamination of beehive frames and walls of beehive by fecation leads to sharp deterioration of the apiary's veterinary and sanitary condition and significant economic damage for beekeepers. Pure culture of pathogenic bacteria served as an object for experiment. The Family of the bacteria was established earlier - Enterobacteriaceae, and was confirmed by "Zhytomyr Regional State Laboratory of the State Service of Ukraine for Food Safety and Consumer Protection". Laboratory diagnostics of dysbiosis in bees caused by enterobacteria was performed in such a sequence: 1. Sowing of pathological material taken from sick bees on selective nutrient media for enterobacteria and extraction of pure culture; 2. Microscopy of typical colonies; 3. Determination of bacteria genus; 4. Determination of bacteria motor activity: 5. Urease test; 6. Indole test; 7. Phenyalaalanine test; 8. Study of basic enzymatic properties of bacteria. In a series of laboratory biochemical studies of pure culture microorganisms isolated from mixed culture from diseased bees the isolated bacterial strain belongs to the Family Enterobacteriaceae, Genus Klebsiella, Species Klebsiella pneumoniae. The novelty of the application of the algorithm for determining the species of Klebsiella pneumoniae enterobacteriae allows to diagnose dysbacterioses in winter-spring and summer-autumn times clearly and economically. The isolated Klebsiella pneumoniae bacteria serve as experimental cultures for testing drugs of various directions and actions in laboratory conditions and are kept at the Department of Microbiology, Pharmacology and Epizootology, Faculty of Veterinary Medicine of Polissya National University (formerly Zhytomyr National Agroecological University). Further application of complex diagnostics of enterobacteriosis of bees, including methods of biochemical typification, will allow to expand etiological factors of bee family collapse.

Key words: Klebsiella pneumoniae, bee colonies, laboratory diagnostics, biochemical typing.

\section{Застосування біохімічного типування у ветеринарній медицині при ентеробактеріозах бджіл для визначення Klebsiella Pneumoniae}

\author{
О. Є. Галатюк, Т. О. Романишина, А. Р. Лахман, В. Л. Бегас, А. М. Андрійчук, Л. О. Солодка
}

Поліський нащіональний університет, м. Житомир, Украӥна 
В статті висвітлена лабораторна діагностика (іп vitro), а саме ідентифікація чистої культури патогенних бактерій бджіл виду Klebsiella Pпеитопіае, при виникненні ентеробактеріозів бджіл у зимово-весняний та літньо-осінній періоди. Ціль дослідження полягала у біохімічній типізації методами гуманної медицини бактерій виду Klebsiella Pпеитопіае, виділених при дисбактеріозах бджіл, які мають характерний симптомокомплекс зниження сили бджолиних сімей, щзо своєю чергою призводить до зниження резистентності бджолиної сім'ї їх опоношенням, повзанням, а згодом, роїнням чи смерті. Забрудення рамок та стінок вуликів випорожненнями призводить до різкого погіршення вететеринарно-санітарного стану пасіки та значних економічних збитків для пасічників. Чиста культура патогенних бактерій слугувала об 'єктом для експерименту. Попередньо встановлено родинну належність бактерій - Enterobacteriaceае, щз було підтверджено “Житомирською регіональною державною лабораторією Державної служби України з питань безпечності харчових продуктів та захисту споживачів”. Лабораторна діагностика дисбіозів бджіл, викликаних ентеробактеріями, проведена у такій послідовності: 1. Висів патологічного матеріалу, відібраного від хворих бджіл, на елективні поживні середовища для ентеробактерій та виділення чистої культури; 2. Мікроскопія типових колоній; 3. Визначення родової належності; 4. Визначення рухової активності бактерій: 5. Тест на уреазу; 6. Тест на індол; 7. Фенілаланіновий тест; 8. Дослідження основних ферментативних властивостей бактерій. За серією лабораторних біохімічних дослідженнь чистої культури мікроорганізмів, виділеної із зміманої культури від хворих на ентеробактеріози бджіл, ізольований штам належить до родини Enterobacteriaceae, роду Klebsiella та виду Klebsiella рпеитопіае. Новизна застосування алгоритму визначення видової належності ентеробактерій бджіл виду Klebsiella рпеитопіае дозволяє чітко та економічно доцільно діагностувати дисбактеріози у зимово-весняний та літньо-осінній періоди. Виділені бактерї виду Klebsiella рпеитопіае слугують експериментальними культурами для проведення випробування препаратів різних напрямів та дій в лабораторних умовах та зберігаються на кафедрі мікробіологї̈, фармакологї та епізоотологї Поліського національного університету (раніше Житомирський національний агроекологічний університет). Подальше застосування комплексної діагностики ентеробактеріозів бджіл, включаючи методи біохімічної типізації, дозволить розширити етіологічні фактори виникнення колапсу бджолних сімей.

Ключові слова: Klebsiella Рпеитопіае, бджолині сім ї, лабораторна діагностика, біохімічне типування.

\section{Ветуп}

В останні роки у світі та в Україні зокрема періодично реєструється масова загибель бджіл (Cornman et al., 2012; Glenny et al., 2017; Galatiuk et al., 2019). Домінуючої єдиної, визнаної науковцями, причини зниження резистентності та сили медоносних бджолиних сімей не існує (Tentcheva et al., 2004; Cox-Foster et al., 2007; Evans et al., 2011; Traynor et al., 2016; Seitz et al., 2016). Вдосконалення стратегії управління та розведення, спрямованої на поліпшення здоров'я бджіл, дозволить зрозуміти біологічні причини втрати у запиленні природних та керованих екосистем (Genersch et al., 2010; Runckel et al., 2011). 32006 року щорічні втрати медоносних бджолиних колоній у США в середньому складають $33 \%$ та мають тенденцію до експресивного динамічного зростання, що становить інтерес для пасічників, виробників різної продукції та вчених (Lee et al., 2015; Traynor et al., 2016).

Аналізуючи кількісно-якісний склад мікробіоти кишечника бджоли та вулика у різні пори року, можна твердити про різноманіття умовно-патогенної мікрофлори (бактерії родів Klebsiella, Enterobacter, Providencia, Proteus, Citrobacter, Escherichia, Pantoea, Morganella, Serratia, яка при сприятливих для неї умовах може мати і негативний вплив на бджолиний організм та на санітарний стан пасічного господарства (Chechotkina et al., 2011; Serdyuchenko, 2017).

Останнім часом зросла кількість випадків ураження верхніх дихальних шляхів та кишечника за захворювання великої рогатої худоби та свиней ентеробактеріозами (Rivera et al., 2018; Chang et al., 2019).

У нашому дослідженні розглянуті сучасні актуальні питання щодо виділення та ідентифікації патогенних ентеробактерій (Klebsiella Pneumoniae) у медоносних бджіл при виникненні масових ентеробактеріозів у зимово-весняний та літній період, а також злітання бджолиних колоній в осінню пору року (Evans et al., 2011; Galatiuk et al., 2019).
В доступних нам літературних джерелах ми не знайшли повідомлень щодо індикації та ідентифікації збудників, які зумовлюють захворювання бджіл ентеробактеріозами.

Одним зі складних завдань в мікробіологічній практиці $\epsilon$ безпомилкове виявлення окремих видів мікроорганізмів, зважаючи на виражену біологічну своєрідність представників різних груп бактерій. Тому діагностика та тестування цілого спектра біологічних і фізіологічних характеристик інфекційних агентів $є$ основним критерієм при постановці діагнозу.

Мета роботи - провести лабораторну ідентифікацію бактерій виду Klebsiella Pneumoniae, виділених при ентеробактеріозах бджіл методами біохімічного типування, які застосовуються у гуманній медицині.

\section{Матеріал і методи досліджень}

Об'єктом для дослідження була чиста культура бактерій виду Klebsiella Pneumoniae, виділена методом Голда на середовищі Ендо (дослідні штами мікроорганізмів були виділені зі змішаної культури від бджіл, уражених ентеробактеріями з типовими клінічними ознаками) (рис. 1). Належність бактерій до родини Enterobacteriaceae була підтверджена “Житомирською регіональною державною лабораторією Державної служби України з питань безпечності харчових продуктів та захисту споживачів" (культивування на елективних середовищах, виділення типових колоній та їх мікроскопія методом Грама, визначення наявності капсули методом Буррі, тест на оксидазну активність) (рис. 2). Визначення рухової активності проводили шляхом висіву уколом у м'ясопептонну желатину (МПЖ) - Klebsiella Pneumoniae - не здатна до руху - росте тільки по ходу укола у стовпчик МПЖ (рис. 2). Встановлення родової та видової приналежності культур визначали біохімічним типуванням 3 лікарями-бактеріологами Державної установи “Житомирський обласний лабораторний центр міністерства охорони здоров'я України”. 


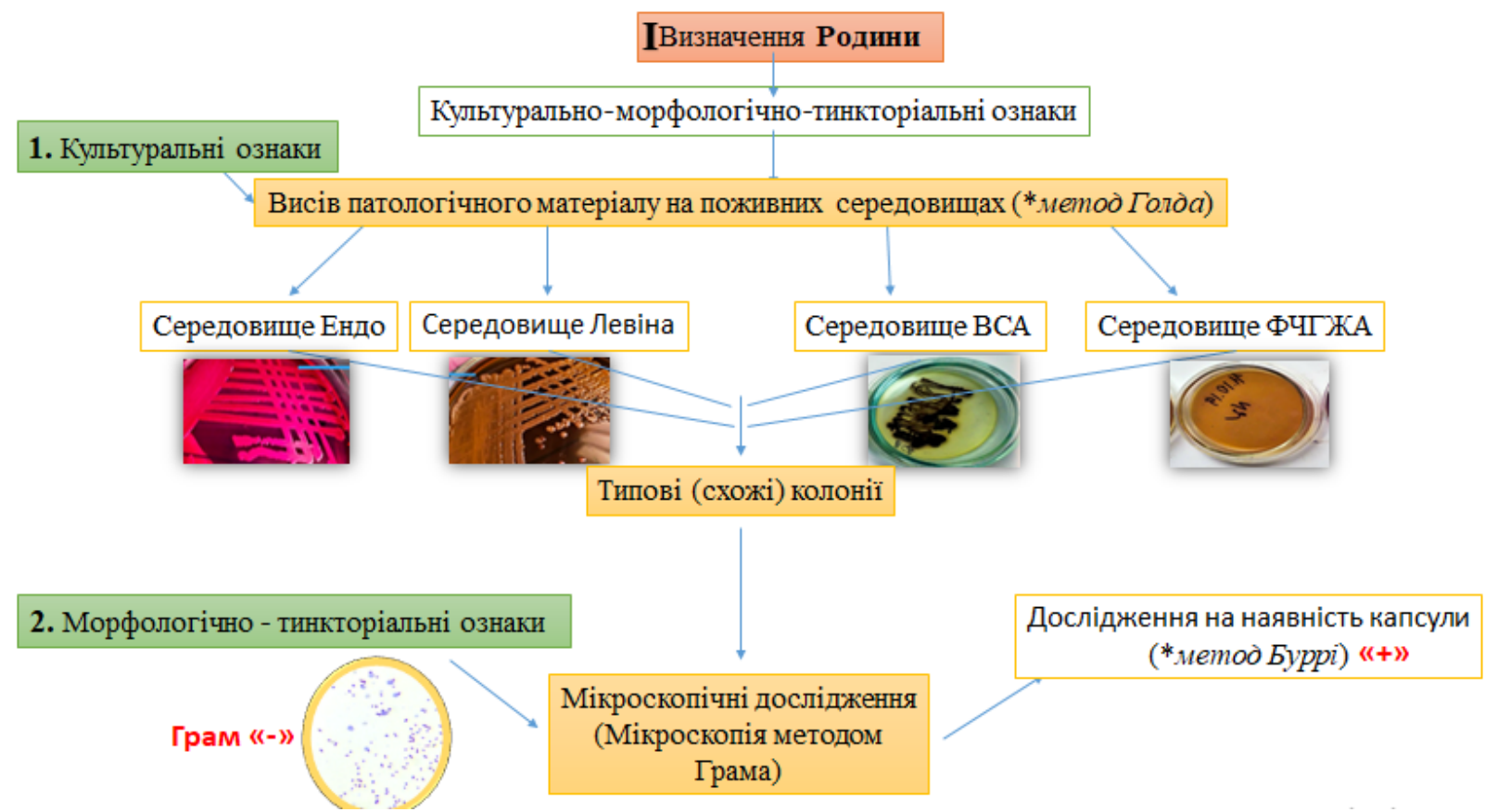

Рис. 1. Етап 1 - Визначення родинної належності бджолиних ентеробактерій виду Klebsiella Pneumoniae Примітка: ВСА - вісмут-сульфітний агар; ФЧГЖА - фіолетово-червоний глюкозо-жовчний агар

\section{Результати та їх обговорення}

Першочерговим чинником інфекційного процесу травної системи в організмі бджоли виступає один або декілька етіологічних факторів одночасно, після чого стає можливим розвиток вторинної бактеріальної інфекції - дисбіозів бджіл (Ravoet et al., 2013; Lee et al., 2015). Дуже важливо серед усіх причин порушення роботи травної системи бджіл виділити домінантну, яка є рушійною силою початку інфекційного процесу в організмі комахи. Це значно полегшить своєчасну та ефективну організацію лікування, зробить можливим профілактику та сприятиме оздоровленню пасік. Завдяки вдалій діагностиці та безпосередньому виділенню збудника можна суттєво зменшити витрати на терапію, а також забезпечити благополучну зимівлю бджіл, запобігаючи можливим хворобам при зниженні резистентності, що спричиняє порушення кількісного та якісного складу мікрофлори середньої кишки бджіл (Chechotkina et al., 2011). Тому для практикуючого пасічника принциповим $€$ питання проведення лікувально-профілактичних заходів на пасіці до початку зимівлі, виконання яких $є$ можливим при правильній постановці діагнозу - визначення видової належності збудника захворювання.

Як відомо, належність мікроорганізмів до певної таксономічної одиниці визначають аналізом сукупності генетичних, морфологічних, фізіологічних та культуральних ознак типових для кожного збудника хвороби. Для визначення виду ентеробактерій у ветеринарній медицині для ссавців та птахів найчастіше використовують серологічні та молекулярногенетичні методи діагностики (Chang et al., 2019). Натомість у галузі бджільництва ідентифікацію Klebsiella Pneumoniae, виділену від хворих бджіл шляхом біохімічного типування, вважаємо найдоцільнішою.

Визначення видової та родової належності досліджуваної чистої культури - одного 3 етіологічних чинників ентеробактеріозів бджіл проводили за схемою (рис. 2).

Зміна кольору індикатора середовища 3 жовтого на малиновий свідчить про зміну $\mathrm{pH}$ внаслідок здатності бактерій виділяти фермент уреазу, який гідролізує сечовину з утворенням лужних продуктів реакції аміаку (рис. 2-5) (Łopieńska-Biernat et al., 2017).

Досліджувана Klebsiella Pneumoniae здатна розщеплювати продукти неповного гідролізу білка - проявляє пептолітичні властивості, колір парадиметиламідобензальдегіда (індикатора) змінився з безбарвного на рожево-бузковий внаслідок виділення індолу (рис. 2-6) (Rivera et al., 2018).

При дослідженні даної культури щодо дезамінування фенілаланіну фенілпіровиноградна кислота не утворювалась, тому вона не могла взаємодіяти 3 хлорним залізом, утворюючи сполуку зеленого кольору Klebsiella Pneumoniae, не здатна дезамінувати фенілаланін (рис. 2-7) (Marievskiy, 2011).

При висіві на скошений агар середовища Кліглера колір середовища не змінювався і чорне кільце не утворювалось, чим можемо інтерпретувати інертність бактерій до лактози та глюкози (рис. 2-8) (Rivera et al., 2018).

Мікроорганізми здатні використовувати цитрат гідрофосфату аммонію як єдине джерело вуглецю із середовища Сімонса з продукцією лугів, що підвищує pH і змінює колір з зеленого на синій (рис. 2-9). Властивість мікроорганізмів утилізувати вуглець малонату та ацетату натрію зумовлює аналогічну зміну кольору середовищ на синій. (рис. 2-10, 11) (Pulcherovskaya et al., 2017). 


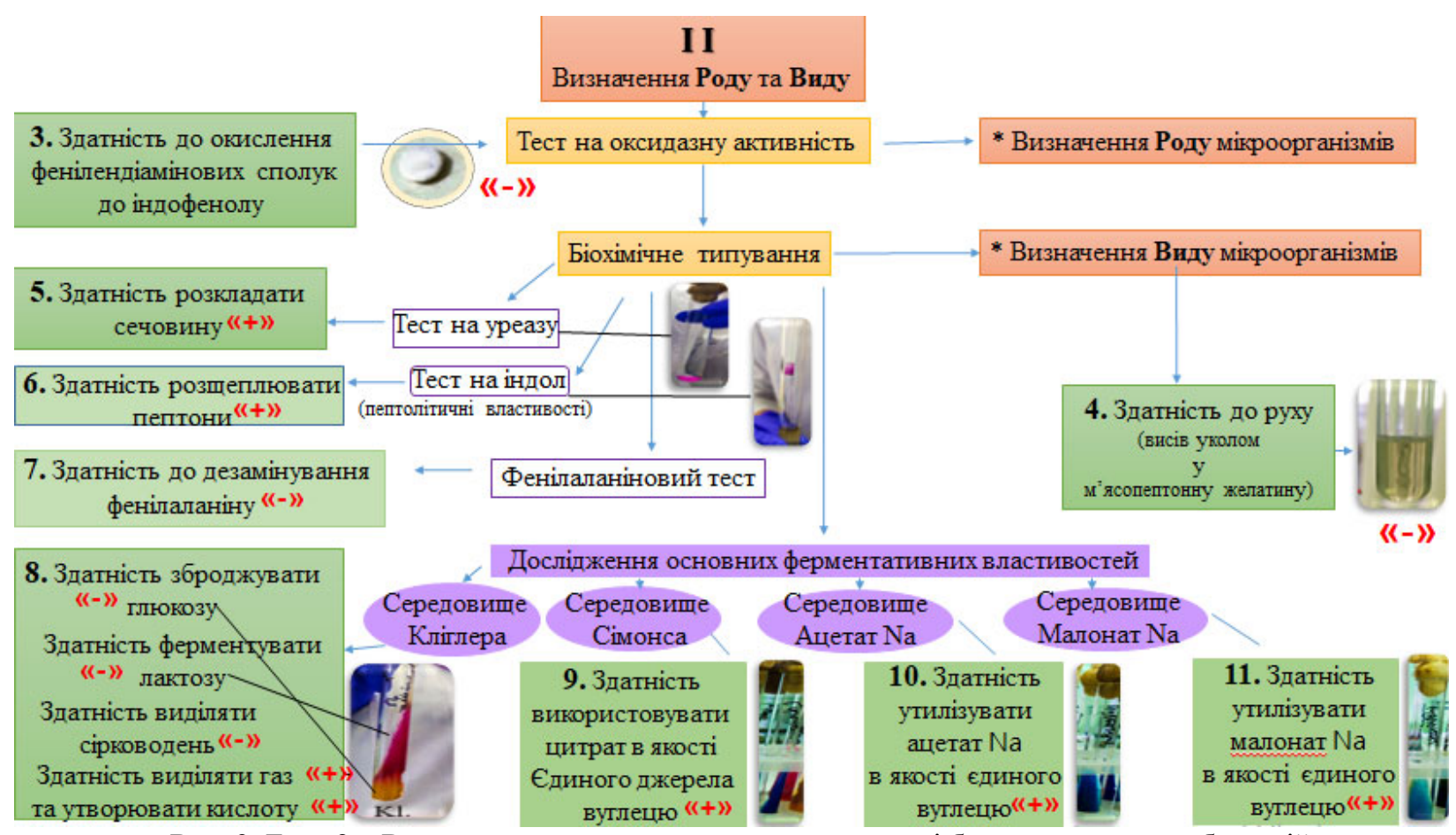

Рис. 2. Етап 2 - Визначення родової та видової належності бджолиних ентеробактерій виду Klebsiella Pneumoniae

Як свідчать результати біохімічних досліджень чистої культури мікроорганізмів, виділеної нами зі змішаної культури від хворих на ентеробактеріози бджіл (рис. 1, 2), досліджуваний ізольований штам належить до родини Enterobacteriaceae, роду Klebsiella та виду Klebsiella pneumoniae.

Групування представників родини Enterobacteriaceae проводять за сукупністю ряду подібних властивостей та морфологічно-культуральних, ферментативних властивостей (Rivera et al., 2018).

Внутрішньовидові відмінності ентеробактерій базуються на генетичному рівні, що можна виявити у молекулярно-біологічних дослідженнях, інтерпретуючи секвенування нуклеотидної послідовності, які, формуючи триплети, спричинюють значущість вірулентності ізоляту (Miró et al., 2013; Seeley et al., 2015).

Основною складовою при постановці діагнозу є лабораторне дослідження патологічного матеріалу економічно доступними та достовірними методами в лабораторних центрах. Тому для нашої роботи використовували загальноприйняті біохімічні тести гуманної медицини (Marievskiy, 2011).

Поширення хвороб шлунково-кишкового тракту трапляються у людей і тварин, причому вагому частину становлять інфекції бактеріального походження, зумовлені активізацією умовно-патогенної мікрофлори кишечника (Chang et al., 2019). Зустрічається багато повідомлень щодо виникнення у людей кишкових проносів, зумовлених бактеріями роду Klebsiella (Miró et al., 2013).

Klebsiella pneumoniae - факультативний пантропний патоген організму людей та тварин (у т. ч. i бджіл) (Ripabelli et al., 2018). Згідно з даними, наданими китайської системою спостереження за антимік- робною резистентністю (CARSS), Klebsiella pneumoniae займає друге місце за поширеністю (20,2 \%) серед ізольованих грамнегативних патогенів. Більшість авторів вказує, що Klebsiella pneumoniae також викликає різні захворювання тварин, включаючи пневмонію, бактеріремію і септицемію (He et al., 2017; Bidewell et al., 2018; Chong et al., 2018). Klebsiella pneumoniae набула високої стійкості до багатьох антибіотиків у зв'язку з широким використанням антимікробних препаратів для стимуляції росту та лікування хвороб у тварин, а саме: поява штамів панхромії, гіпервірулентних ізолятів та штамів 3 множинною лікувальною стійкістю викликає великі труднощі у профілактиці та лікуванні інфекцій, зумовлених бактеріями виду Klebsiella pneumoniae (Oliva et al., 2015; Prokesch et al., 2016; Catalán-Nájera et al., 2017; Sonnevend et al., 2017; Xu et al., 2018).

Тому виділення високовірулентних та ідентифікація окремих штамів Klebsiella pneumoniae від хворих бджіл звузить пошук ефективних препаратів для боротьби 3 полірезистентними збудниками кишкових дисбіозів бджіл.

\section{Висновки}

1. Серією послідовних лабораторних досліджень фізіологічних властивостей бактерій чистої культури мікроорганізмів, виділених зі змішаної культури від хворих на ентеробактеріози бджіл, доведено що ізольований штам належить до виду Klebsiella pneumoniae.

2. Запропонований алгоритм визначення видової належності ентеробактерій у галузі бджільництва 
дозволяє виявляти збудників бактерій, які належать до родини Enterobacteriaceae.

3. Ідентифікована нами Klebsiella Pneumoniae може бути використана як спеціально-випробувальна культура для вивчення напрямку дії засобів лікування та профілактики кишкових інфекцій у бджіл (in vitro), зумовлених бактеріями виду Klebsiella Pneumoniae.

\section{References}

Bidewell, C. A., Williamson, S. M., Rogers, J., Tang, Y., Ellis, R. J., Petrovska, L., \& Abuoun, M. (2018). Emergence of Klebsiella pneumoniae subspecies pneumoniae as a cause of septicaemia in pigs in England. PloS one, 13(2). doi: 10.1371/journal.pone.0191958.

Catalán-Nájera, J. C., Garza-Ramos, U., \& BarriosCamacho, H. (2017). Hypervirulence and hypermucoviscosity: two different but complementary Klebsiella spp. phenotypes? Virulence, 8(7), 1111-1123. doi: 10.1080/21505594.2017.1317412.

Chang, M. H., Chen, G. J., \& Lo, D. Y. (2019). Chromosomal locations of mcr-1 in Klebsiella pneumoniae and Enterobacter cloacae from dogs. Taiwan Veterinary Journal, 45(03), 79-84. doi: 10.1142/S168264851972003X.

Chechotkina, U. E., Evteeva, N. I., Rechkin, A. I., \& Radaev, A. A. (2011) Enterobacterium as part of the microflora of the digestive system of honey bees in different seasons. N.I. Lobachevsky Bulletin of Nizhny Novgorod University, 2-2, 149-153 (in Russian).

Chong, Y., Shimoda, S., \& Shimono, N. (2018). Current epidemiology, genetic evolution and clinical impact of extended-spectrum $\beta$-lactamase-producing Escherichia coli and Klebsiella pneumoniae. Infection, Genetics and Evolution, 61, 185-188. doi: 10.1016/j.meegid.2018.04.005.

Cornman, R. S., Tarpy, D. R., Chen, Y., Jeffreys, L., Lopez, D., Pettis, J. S., \& Evans, J. D. (2012). Pathogen webs in collapsing honey bee colonies. PLoS one, 7(8). doi: 10.1371/journal.pone.0043562.

Cox-Foster, D. L., Conlan, S., Holmes, E. C., Palacios, G., Evans, J. D., Moran, N. A., Quan, P. L., Briese, T., Hornig, M., Geiser, D. M., Martinson, V., van Engelsdorp, D., Kalkstein, A. L., Drysdale, A., Hui, J., Zhai, J., Cui, L., Hutchison, S. K., Simons, J. F., Egholm, M., Pettis, J. S., \& Lipkin, W. I. (2007). A metagenomic survey of microbes in honey bee colony collapse disorder. Science, 318, 283-287. doi: 10.1126/science.1146498.

Evans, J. D., \& Schwarz, R. S. (2011). Bees brought to their knees: microbes affecting honey bee health. Trends in microbiology, 19(12), 614-620. doi: 10.1016/j.tim.2011.09.003.

Galatyuk, O., Romanishina, T., Lakhman, A., Lysenko, O., \& Shimanska, V. (2020). Stiykist' patohennykh enterobakteriy bdzhil do eksperymental'noho yodovmisnoho dezinfektantu "Yodis Dez № 2", Naukovi horyzonty, 1(86), 71-78. doi: 10.33249/2663-21442020-86-1-71-78 (in Ukrainian).

Genersch, E., von der Ohe, W., Kaatz, H., Schroeder, A., Otten, C., Bu“chler, R., Berg, S., Ritter, W., Mühlen, W., Gisder, S., Meixner, M., Liebig, G., \&
Rosenkranz, P. (2010). The German bee monitoring project: a long term study to understand periodically high winter losses of honey bee colonies. Apidologie, 41(3), 332-352. doi: 10.1051/apido/2010014.

Glenny, W., Cavigli, I., Daughenbaugh, K. F., Radford, R., Kegley, S. E., \& Flenniken, M. L. (2017). Honey bee (Apis mellifera) colony health and pathogen composition in migratory beekeeping operations involved in California almond pollination. PloS one, 12(8). doi: 10.1371/journal.pone.0182814.

He, T., Wang, Y., Sun, L., Pang, M., Zhang, L., \& Wang, R. (2016). Occurrence and characterization of bla NDM-5-positive Klebsiella pneumoniae isolates from dairy cows in Jiangsu, China. Journal of Antimicrobial Chemotherapy, 72(1), 90-94. doi: 10.1093/jac/dkw357.

Lee, K. V., Steinhauer, N., Rennich, K., Wilson, M. E., Tarpy, D. R., Caron, D. M., Rose R, Delaplane, K. S., Baylis, K., Lengerich, E. J., Pettis, J., Skinner, J. A., Wilkes, J. T., Sagili, R., \& van Engelsdorp, D. (2015). A national survey of managed honey bee 2013-2014 annual colony losses in the USA. Apidologie, 46, 292-305. doi: 10.1007/s13592-015-0356-Z.

Łopieńska-Biernat, E., Sokół, R., Michalczyk, M., Żółtowska, K., \& Stryiński, R. (2017). Biochemical status of feral honey bees (Apis mellifera) infested with various pathogens, Journal of Apicultural Research, 56(5), 606615, doi: 10.1080/00218839.2017.1343020.

Marievskiy, V. F. (2011). Medical Microbiology, Virology and Immunology: A Textbook for Students of Higher Medical Education (4), Vinnytsia, New book (in Ukrainian).

Miró, E., Grünbaum, F., Gómez, L., Rivera, A., Mirelis, B., Coll, P., \& Navarro, F. (2013). Characterization of aminoglycoside-modifying enzymes in enterobacteriaceae clinical strains and characterization of the plasmids implicated in their diffusion. Microb.DrugResist, 19(2), 94-99. doi: 10.1089/mdr.2012.0125.

Oliva, A., Mascellino, M. T., Cipolla, A., D’Abramo, A., De Rosa, A., Savinelli, S., RosaCiardi, M., Mastroianni, M. C., \& Vullo, V. (2015). Therapeutic strategy for pandrug-resistant Klebsiella pneumoniae severe infections: short-course treatment with colistin increases the in vivo and in vitro activity of double carbapenem regimen. International Journal of Infectious Diseases, 33, 132-134. doi: 10.1016/j.ijid.2015.01.011.

Prokesch, B. C., Tekippe, M., Kim, J., Raj, P., TeKippe, E. M., \& Greenberg, D. E. (2016). Primary osteomyelitis caused by hypervirulent Klebsiella pneumoniae. The Lancet Infectious Diseases, 16(9), 190-195. doi: 10.1016/S1473-3099(16)30021-4.

Pulcherovskaya, L. P., Vasilev, D. A., \& Zolotuhin, S. N. (2017). Isolation of the genus Citrobacter bacteria. Bulletin of the Ulyanovsk State Agricultural Academy, 3(39), 83-87. doi: 10.18286/1816-4501-2017-383-87.

Ravoet, J., Maharramov, J., Meeus, I., De Smet, L., Wenseleers, T., Smagghe, G., \& de Graaf, D. C. (2013). Comprehensive Bee Pathogen Screening in Belgium Reveals Crithidia mellificae as a New Contributory Factor to Winter Mortality. Plos One, 8. doi: 10.1371/journal.pone.0072443. 
Ripabelli, G., Tamburro, M., Guerrizio, G., Fanelli, I., Flocco, R., Scutellà, M., \& Sammarco, M. L. (2018). Tracking multidrug-resistant Klebsiella pneumoniae from an Italian hospital: molecular epidemiology and surveillance by PFGE, RAPD and PCR-based resistance genes prevalence. Current microbiology, 75(8), 977-987. doi: 10.1007/s00284-018-1475-3.

Rivera, A., Cedillo, L., Perez, J., Hernandez, F., Romero, O., \& Rodriguez, N. (2018). Isolation of Enterobacteria and Spiroplasmas from Apis mellifera. Journal of Entomology and Zoology Studies, 6(3), 900-902.

Runckel, C., Flenniken, M. L., Engel, J. C., Ruby, J. G., Ganem, D., Andino, R., \& DeRisi, J. L. (2011). Temporal analysis of the honey bee microbiome reveals four novel viruses and seasonal prevalence of known viruses, Nosema, and Crithidia. PLoS One, 6. doi: 10.1371/journal.pone.0020656.

Seeley, T. D., Tarpy, D. R., Griffin, S. R., Carcione, A., Delaney, D. A. (2015). A survivor population of wild colonies of European honey bees in the northeastern United States: Investigating its genetic structure. Apidologie, 46, 654-666. doi: 10.1007/s13592-0150355-0.

Seitz, N., Traynor, K. S., Steinhauer, N., Rennich, K., Wilson, M. E., Ellis, J. D., Rose, R. L., Tarpy, D. R.., Sagili, R. R., Caron, D. M., Delaplane, K. S., Rangel, Ju. K., Lee, K. M., Baylis, K. T., Wilkes, J. T., Skinner, J., Pettis, J. S., \& Engelsdorp, D. S. (2016). A national survey of managed honey bee 2014-2015 annual colo- ny losses in the USA. Journal of Apicultural Research, 54, 292-304. doi: 10.1080/00218839.2016.1153294.

Serdyuchenko, I. V. (2017). Quantitative evaluation of the digestive tract microflora of the bees before and after wintering, 2, 286-289 (in Russian).

Sonnevend, Á., Ghazawi, A., Hashmey, R., Haidermota, A., Girgis, S., Alfaresi, M., Omar, M., Paterson, D., Zowawi, H. M., \& Pál, T. (2017). Multihospital occurrence of pan-resistant Klebsiella pneumoniae sequence type 147 with an ISEcp1-directed blaOXA-181 insertion in the mgrB gene in the United Arab Emirates. Antimicrobial agents and chemotherapy, 61(7). doi: 10.1128/AAC.00418-17.

Tentcheva, D., Gauthier, L., Zappulla, N., Dainat, B., Cousserans, F., Colin, M., \& Bergoin, M. (2004). Prevalence and seasonal variations of six bee viruses in Apis mellifera $L$. and Varroa destructor mite populations in France. Applied and Environmental Microbiology, 70, 7185-7191. doi: 10.1128/AEM.70.12.7185-7191.2004.

Traynor, K. S., Rennich, K., Forsgren, E., Rose, R., Pettis, J., Kunkel, G., Madella, S., Evans, J., Lopez, D., \& Engelsdorp, D. (2016). Multiyear survey targeting disease incidence in US honey bees. Apidologie, 47, 325-347. doi: 10.1007/s13592-016-0431-0.

Xu, M., Li, A., Kong, H., Zhang, W., Chen, H., Fu, Y., \& $\mathrm{Fu}, \mathrm{Y}$. (2018). Endogenous endophthalmitis caused by a multidrug-resistant hypervirulent Klebsiella pneumoniae strain belonging to a novel single locus variant of ST23: first case report in China. BMC infectious diseases, 18(1), 669. doi: 10.1186/s12879-018-3109-6. 